\title{
Pengaruh Kemandirian Belajar Dan Efikasi Diri Terhadap Pemahaman Akuntansi Siswa
}

\author{
Ana Merdekawaty ${ }^{1}$, Fatmawati Fatmawati ${ }^{2}$ \\ 1,2 Universitas Samawa, Sumbawa Besar \\ 12anamerdekawaty@universitassamawa.ac.id, ${ }^{2}$ fatmawati@universitassamawa.ac.id
}

\begin{abstract}
The subject of accounting is one of the subjects that is considered difficult and requires student interest in learning so it is not surprising that student learning achievement is relatively low. This is because students' mastery of accounting subjects is still low. This study aims to determine the effect of learning independence and self-efficacy on the understanding of trading company accounting for students at SMA Negeri 1 Moyo Utara. This type of research is associative research with 56 respondents who were determined by the census method. Data collection techniques are questionnaires and documentation. Data collection tool uses a questionnaire. Analysis of the data used is multiple linear regression. The results showed that learning independence and self-efficacy variables had a positive and significant effect both partially and simultaneously on students 'understanding of accounting, and self-efficacy variables were the most dominant influence on students' understanding of accounting in the accounting material of trading companies. Based on the coefficient of determination, the variables of learning independence and self-efficacy contributed $82.60 \%$ to the understanding of student accounting. Based on the results of the study, it is suggested to teachers and students to be able to work together to create a quality learning process so that students can improve their understanding of the material being studied. Keywords: Learning Independence, Self-Efficacy, Accounting Understanding, Students
\end{abstract}

\section{Pendahuluan}

Mata pelajaran ekonomi mencakup materi akuntansi yang merupakan salah satu matapelajaran wajib bagi siswa SMA/MA yang mengambil jurusan IPS.Sebagian besar siswa menganggap belajar akuntansi itu sulit karena berhubungan dengan angka-angka. Banyak juga yang berpikir belajar akuntansi itu sekedar menghitung uang khayalan yang tidak ada secara nyata.

Akuntansi merupakan mata pelajaran yang unik. Hal tersebutdikarenakan akuntansi termasuk dalam kelompok ilmu sosial yang didalamnya terdapat seni menganalisis, mengelompokan, mencatat dan melaporkan data akuntansi menjadi laporan keuangan. Selain itu, matapelajaran akuntansi menuntut kemampuan siswa yang lebih untukmemahami konsep-konsep dasar, prinsip, dan prosedur akuntansidengan baik dan benar. Konsekuensinya bila seorang siswa tidak memahami langkah-langkah dasar maka seorang siswa akan kesulitan untuk memahami langkah selanjutnya yang lebih kompleks, kondisi ini tentu berimplikasi kepada kegagalan dalam pembelajaran (Patmahsari, 2012).

Menurut Suwardjono (dalam Indra, 2018) pengetahuan akuntansi dapat dipandang dari dua sisi pengertianyaitu sebagai pengetahuan profesi (keahlian) yang dipraktekkan di dunia nyata dan sekaligussebagai suatu disiplin pengetahuan yang diajarkan di perguruan tinggi. Akuntansi sebagai objek pengetahuan di perguruan tinggi, akademisi memandang akuntansi sebagai dua bidang kajianyaitu bidang praktek dan teori. Bidang praktek berkepentingan dengan masalah bagaimana praktek dijalankan sesuai dengan prinsip akuntansi. Bidang teori berkepentingan dengan penjelasan, deskripsi, dan argumen yang dianggap melandasi praktek akuntansi yang semuanyadicakup dalam suatu pengetahuan yang disebut teori akuntansi (Yuniani, 2010).

Paham dalam Kamus Besar Bahasa Indonesia memiliki arti pandai atau mengerti benar sedangkan pemahaman adalah proses, cara, perbuatan memahami atau memahamkan. Ini berarti bahwa orang yang memiliki pemahaman akuntansi adalah orang yang pandai dan mengerti benar akuntansi.nilai yang diperoleh mahasiswa merupakan indikator keberhasilan 
mahasiswa dalam memahami suatu ilmu. Penguasaan pengetahuan atau keterampilan yang dikembangkan oleh mata pelajaran, lazimnya ditunjukkan dengan nilai tes atau angka yang diberikan oleh guru/dosen (Muliono dalam Hanifah \& Abdullah, 2001). Nilai yang diperoleh siswa mempunyai fungsi ganda, sebagai ukuran keberhasilan dalam mempelajari mata pelajaran dan sekaligus sebagai alat evaluasi keberhasilan mata pelajaran itu sendiri.

Pemahaman akuntansi merupakan salah satu indikator untuk mengetahui keberhasilan belajar pada mata pelajaran akuntansi. Dengan pemahaman yang baik diharapkan dapat meningkatkan hasil belajar siswa. Hasil belajar yang baik mampu menggambarkan kualitas pendidikan yang baik pula. Upaya yang dapat di lakukan untuk meningkatkan pemahaman siswa di antaranya dengan meningkatkan kemandirian belajar siswa dan efikasi diri.

Kemandirian belajar adalah proses aktif dan konstruktif mahasiswa dalam menetapkan tujuan untuk proses belajarnya dan berusaha untuk memonitor, meregulasi, dan mengontrol kognisi, motivasi, dan perilaku, yang kemudian semuanya diarahkan dan didorong oleh tujuan dan mengutamakan konteks lingkungan (Adicondro dan Purnamasari , 2011: 18).

Kemandirian adalah unsur penting dalam belajar karena dengan adanya kemandirian belajar, keberhasilan dan prestasi siswa akan lebih mudah diperoleh. Diantara bentuk-bentuk kemandirian belajar siswa adalah kesadaran diri untuk belajar, adanya rasa percaya diri dalam menyesuaikan tugas-tugasnya, tidak mencontoh teman, tidak mencontek buku saat ujian dan memiliki pribadi yang berkualitas. Masalah yang bisa terjadi dari rendahnya kemandirian belajar yaitu berdampak pada prestasi belajar siswa yang menurun, kurangnya tanggungjawab siswa dan ketergantungan terhadap orang lain dalam mengambil keputusan maupun dalam mengerjakan tugas-tugas sekolah (Lestari, 2015).

Mengenai upaya pembentukan kemandirian belajar ini juga ditegaskan dalam UndangUndang Republik Indonesia No. 20 Th 2003 tentang Sistem Pendidikan Nasional. Pendidikan Nasional berfungsi mengembangkan kemampuan dan membentuk watak serta peradapan bangsa yang bermartabat dalam rangka mencerdaskan kehidupan bangsa bertujuan untuk berkembangnya potensi peserta didik agar menjadi manusia yang beriman dan bertaqwa kepada Tuhan Yang Maha Esa, berakhlak mulia, sehat, berilmu, cakap, Kreatif, mandiri dan menjadi warga negara yang demokratis dan bertanggung jawab.

Kemandirian belajar siswa itu dapat ditunjukan melalui adanya hasrat bersaing siswa, siswa memiliki kepercayaan diri dan bertanggungjawab terhadap apa yang dilakukan, serta meningkatnya minat dan motivasi siswa, dan meningkatnya prestasi siswa di sekolah.

Menurut Prayitno (dalam Saputri, 2013: 2) dalam belajar mandiri mahasiswa dituntut untuk mampu mandiri dalam hal: a) mengakses materi dan sumber belajar; b) Memahi materi belajar; c) Mengaktualisasi diri di dalam kelas, d) Merekam materi pelajaran yang dibaca dan diterangkan; e) Mengerjakan tugas; f) Belajar bersama dengan sejawat mahasiswa (belajar kelompok); g) Berdiskusi dan beragumentasi; h) Membaca dan menulis karya ilmiah; i) Mempersiapkan dan mengikuti ujian; j) Menganalisis dan menindaklanjuti hasil ujian;k) menolak tekanan untuk mengikuti tuntutan orang lain tentang keyakinan (belief) dalam bidang nilai.

Berdasarkan studi pendahuluan di SMA Negeri 1 Moyo Utara, tingkat kemandirian belajar siswa masih tergolong rendah. Hal ini terlihat dari masih banyaknya siswa yang tidak mengerjakan PR, bahkan sering dijumpai bahwa siswa mengerjakan tugas pada pagi hari sebelum jam pelajaran dimulai dengan melihat jawaban temannya yang pandai. Ketergantungan pada siswa lain yang memiliki kemampuan lebih dalam mengerjakan tugas atau pekerjaan rumah seakan telah menjadi suatu kebiasaan, bahkan pada saat ulangan pun mereka cenderung mengandalkan temannya karena tidak percaya dengan kemampuan yang dimilikinya sendiri.

p-ISSN 2337-571X | e-ISSN 2541-562X

(C)Prodi Pendidikan Ekonomi Unswagati Cirebon 
Peneliti menduga dalam proses pembelajaran akuntansi sangat di butuhkan faktor internal, karena didalam prosespembelajaran akuntansi memerlukan kemampuan konsep (dalam hal ini siswa memiliki kemampuan memahami konsep-konsep dasar akuntansi) dan prosedural (dalam hal ini siswa memiliki kemampuan dalam penyusunan tahap-tahap siklus akuntansi) yang baik, maka siswa dituntut untuk memiliki kemandirian belajar agar dapat mengembangkan konsep dan keterampilan dalam proses pembelajaran akuntansi. Oleh karena itu untuk meningkatkan pemahaman dalam pembelajaran akuntansi, siswa harus memiliki kemandirian belajar.

Selain kemandirian belajar, tingkat pemahaman siswa juga dipengaruhi oleh faktor efikasi diri. Menurut Kreitner dan Kinicki (2007) Efikasi diri adalah keyakinan seseorang tentang dirinya kemungkinan berhasil menyelesaikan tugas tertentu. Efikasi diri mengacu pada kepercayaan individu akan kemampuannya untuk sukses dalam melakukan sesuatu. Efikasi diri merupakan penilaian individu terhadap kemampuan atau kompetensinya untuk melakukan suatu tugas, mencapai suatu tujuan, atau mengatasi hambatan dalam belajar. efikasi diri memiliki pengaruh yang baik dalam menentukan keberhasilan belajar yang akan dicapai oleh peserta didik, karena dengan efikasi diri yang tinggi akan memberikan inisiatif dan ketekunan untuk meningkatkan usaha dan kemampuan seorang untuk mendapatkan apa yang diinginkannya.

Efikasi diri merupakan ekspetasi spesifik yang kita yakini tentang kemampuan kita dalam mencapai sesuatu atau mengerjakan tugas. Keyakinan atas suatu hal tersebut dapat terwujud dalam magnitude atau keyakinan untuk menyelesaikan tugas yang dianggap sulit, kemudian generality atau keyakinan dalam menyelesaikan segala variasi tugas, serta strengthatau keyakinan akan kemampuan untuk menyelesaikan tugas. Hal tersebut juga sesuai dengan pendapat yang dikemukakan oleh Adicondro (2011) mengatakan jika seseorang memiliki efikasi diri yang tingi maka akan memiliki keyakinan mengenai kemampuannya dalam mengorganisasi dan menyelesaikan suatu tugas belajar yang diperlukan untuk mencapai hasil belajar tertentu dalam berbagai bentuk dan tingkat kesulitan. Sebaliknya jika seseorang dengan efikasi diri yang rendah akan sangat mempengaruhi seseorang dalam menyelesaikan tugasnya untuk mencapai hasil tertentu.

Jadi bisa dikatakan efikasi diri adalah keyakinan seseorang mengenai sejauh mana ia mampu mengerjakan tugas, mencapai tujuan, dan merencanakan tindakan untuk mencapai suatu tujuan.Ketika seseorang mempunyai self efficacy tinggi, dia tahu bahwa ia bisa mengerjakan suatu hal.

Berdasarkan pemaparan di atas, maka permasalahan yang akan dikaji dalam penelitian ini adalah: Apakah terdapat pengaruh secara parsial dan simultan dari variabel kemandirian belajar dan efikasi diri terhadap pemahaman akuntansi siswa SMA Negeri 1 Moyo Utara dan variabel manakah berpengaruh dominan terhadap pemahaman Akuntasi siswa. Penelitian ini penting dilakukan karena hasilnya dapat dijadikan dasar bagi pengelola pendidikan, khususnya guru akuntansi dalam meningkatkan pemahaman siswa agar prestasi belajar siswa lebih baik lagi sesuai dengan tujuan pembelajaran.

Berdasarkan tujuan penelitian, landasan teori dapat dirumuskan hipotesis sebagai berikut:

1. Terdapat pengaruh yang siginfikan secara parsial dan simultan dari variabel kemandirian belajar dan efikasi diri terhadap pemahaman akuntansi siswa SMAN 1 Moyo Utara

2. Diduga variabel yang berpengaruh lebih dominan terhadap pemahaman akuntansi siswa SMAN 1 Moyo Utara adalah efikasi diri.

p-ISSN 2337-571X | e-ISSN 2541-562X

(C)Prodi Pendidikan Ekonomi Unswagati Cirebon 


\section{Metode Penelitian}

Ditinjau dari hubungan antara variabel bebas dan variabel terikat, maka penelitian ini merupakan penelitian asosiatif yaitu penelitian yang bertujuan untuk mengetahui hubungan dua variabel atau lebih. Hubungan yang digunakan dalam penelitian ini adalah hubungan kausal, yaitu hubungan yang bersifat sebab akibat. Responden dalam penelitian ini adalah siswa SMAN 1 Moyo Utara kelas X IPS yang berjumlah 56 orang. Penentuan jumlah responden berdasarkan sensus, yaitu semua populasi dijadikan responden. Sumber data berupa data primer yang diperoleh secara langsung dari jawaban atas angket yang diberikan kepada responden. Teknik pengumpulan data menggunakan angket dan dokumantasi sedangkan alat pengumpulan data dalam penelitian ini a menggunakan kuesioner (daftar pertanyaan). Kuisioner merupakan alat bantu utama untuk mengumpulkan data variabel penelitian dengan menyebarkan serangkaian pertanyaan tertulis kepada responden. Alternatif jawaban kuisioner mengacu pada teknik skala likert dengan lima alternatif jawaban, yaitu sangat setuju, setuju, kurang setuju, tidak setuju dan sangat tidak setuju.

Uji Instrumen Penelitian menggunakan uji validitas dan reliabilitas. Uji validitas menunjukkan sejauh mana tingkat ketepatan penggunaan alat ukur terhadap gejala yang ingin diukur. Kuesioner dikatakan valid jika setiap butir pertanyaan memiliki keterkaitan yang tinggi. Sedangkan uji reliabilitasmenunjukkan konsistensi suatu alat ukur di dalam mengukur gejala yang sama. Suatu konstruk atau variabel dikatakan reliabel apabila memberikan nilai cronbach alpha $(\boldsymbol{\alpha})>0,6$. Uji Asumsi Klasik yang digunakan yaitu Uji Normalitas, uji Multikolinieritas, uji Heteroskedastisitas dan Autokorelasi.

Sedangkan untuk uji Hipotesis menggunakan Analisa Regresi Berganda, Uji t, Uji F dan Uji Koefisien Determinasi. Analisa Regresi Berganda digunakan untuk mengetahui pengaruh variabel independen terhadap variabel dependen. Formulasi yang dihasilkan dalam bentuk Y $=\mathrm{a}+\mathrm{b}_{1} \mathrm{X}_{1}+\mathrm{b}_{2} \mathrm{X}_{2}+\mathrm{b}_{3} \mathrm{X}_{3}+\mathrm{e}$. Uji t digunakan untuk mengetahui derajat keyakinan antara variabel yang diteliti secara parsial. Uji $\mathrm{F}$ digunakan untuk mengetahui besarnya pengaruh variabel kemandirian belajar dan efikasi diri secara simultan terhadap pemahaman akuntansi siswa dan Uji Koefisien determinasi ( $\mathrm{R}^{2}$ ) untuk mengukur seberapa besar proporsi variasi dari variabel dependen dapat dijelaskan oleh variabel independen.

\section{Hasil dan Pembahasan}

\section{Analisis Regresi Linier Berganda}

Analisis Regresi Linier Berganda adalah analisis untuk mengukur besarnya pengaruh variabel kemandirian belajar dan efikasi diri terhadap pemahaman akuntansi siswa SMAN 1 Moyo Utara. Setelah dilakukan pengolahan data diperoleh hasil pada tabel berikut:

Tabel 1. Hasil Analisis Regresi Berganda dan Koefisien Regresi

\begin{tabular}{llllll}
\hline \multicolumn{1}{c}{ Model } & B & se & Beta & T & Sig. \\
\hline (Constant) & 2.181 & 0.386 & & 5.656 & 0.000 \\
\hline $\begin{array}{l}\text { Kemandirian } \\
\text { Belajar }\end{array}$ & 0.347 & 0.108 & 0.419 & 3.223 & 0.002 \\
\hline Efikasi Diri & 0.535 & 0.144 & 0.483 & 3.712 & 0.001
\end{tabular}

Sumber: Hasil Penelitian 2018

Berdasarkan hasil perhitungan regresi dalam tabel di atas, maka dapat dibuat persamaan sebagai berikut: 
$\mathrm{Y}=\mathbf{2 , 1 8 1}+\mathbf{0 , 3 4 7} \mathrm{X} 1+\mathbf{0 , 5 3 5} \mathrm{X} 2+\mathrm{e}$

Keterangan :

$\mathrm{Y}=$ Pemahaman Akuntansi

$\mathrm{X} 1$ = Kemandirian Belajar

$\mathrm{X} 2$ = Efikasi Diri

$\mathrm{e} \quad=$ error

Dari persamaan regresi diketahui bahwa bila meningkat setiap satu satuan pada kemandirian belajar dan efikasi diri maka semakin meningkat pemahaman akuntansi perusahaan dagang siswa.

\section{Uji Hipotesa}

Selanjutnya dari pengolahan data untuk menjawab hipotesa diperoleh hasil sebagai berikut. Berdasarkan hasil uji t statistik diketahui bahwa kemandirian belajar dengan nilai $t_{\text {hitung }}=3,223$ dan signifikansi $p=0,002<0,05$, serta efikasi diri dengan nilai thitung $=3,712$ dan signifikansi $\mathrm{p}=0,001<0,05$ dimana $\mathrm{t}_{\text {tabel }}=1,679$ sehingga berdasarkan hasill tersebut maka $t_{\text {hitung }}>t_{\text {tabel }}$ yang berarti kemandirian belajar dan efikasi diri berpengaruh secara parsial terhadap pemahaman akuntansi siswa. Berdasarkan hasil uji statistik diketahui nilai $\mathrm{F}_{\text {hitung }}=$ 59,893 dimana $F_{\text {tabel }}=4,06$ sehingga $F_{\text {hitung }}>F_{\text {tabel }}$ dengan signifikansi $p=0,000<0,05$ yang berarti kemandirian belajar dan efikasi diri secara simultan berpengaruh terhadap pemahaman akuntansi siswa. Hasil penelitian juga menunjukkan koefisien determinasi $\left(\mathrm{R}^{2}\right)$ $=0,826$ yang artinya $82,6 \%$ pemahaman akuntansi siswa dapat pengaruhi oleh variabel kemandirian belajar dan efikasi diri dan sisanya 14,4\% dipengaruhi oleh faktor lain yang tidak diteliti dalam penelitian ini

\section{Pengaruh Kemandirian Belajar terhadap Pemahaman Akuntansi Siswa}

Hasil temuan analisis ini memberikan informasi, bahwa kemandirian belajar berpengaruh terhadap pemahaman akuntansi siswa SMAN 1 Moyo Hulu. Hasil penelitian ini dapat ditinjau dari pendapat Suhendri (2012) yang menyatakan bahwa kemandirian belajar merupakan suatu aktivitas belajar yang dilakukan siswa tanpa bergantung kepada bantuan orang lain baik teman maupun gurunya dalam mencapai tujuan belajar yaitu menguasai materi atau pengetahuan dengan baik dengan kesadarannya sendiri serta siswa dapat mengaplikasikan pengetahuannya dalam menyelesaikan masalah-masalah dalam kehidupan sehari-hari.

Dengan melihat hasil penelitian serta pendapat di atas dapat diketahui bahwa kemandirian yang dimiliki siswa memberikan kemampuan siswa untuk dapat memahami akuntansi perusahaan dagang yang diperoleh dari sekolah melalui guru. Kemandirian belajar pada siswa tersebut menggambarkan siswa memiliki kekuatan untuk belajar sendiri agar dapat memahami setiap materi. Kemandirian ini dapat diterapkan sejak dini dan bilamana ada materi yang kurang dipahami, maka siswa dapat mencari solusi melalui berbagai cara yang diantaranya dapat dilakukan dengan mencari melalui internet ataupun dan bertanya kembali guru bersangkutan.Kemandirian belajar dapat terlihat pada kebiasaan-kebiasaan belajar siswa sehari-hari seperti cara merencanakan dan melakukan belajar. Kemandirian belajar yang tinggi dari siswa sangat diperlukan dalam peningkatan prestasi belajar.

\section{Pengaruh Efikasi Diri terhadap Pemahaman Akuntansi Siswa}

Berdasarkan hasil uji statistik diperoleh nilai $t_{\text {hitung }}=3,712>t_{\text {tabel }}=1,679$ dan signifikansi $\mathrm{p}=0,001<0,05$ yang menunjukkan bahwa kemandirian belajar berpengaruh terhadap pemahaman akuntansi siswa pada materi akuntansi perusahaan dagang. Hal ini sesuai seperti yang dijelaskan olehDjamarah (2011:177) faktor yang mempengaruhi prestasi belajar p-ISSN 2337-571X | e-ISSN 2541-562X

(C) Prodi Pendidikan Ekonomi Unswagati Cirebon 
dikelompokkan menjadi dua yakni pertama, faktor internal yang meliputi faktor fisiologi ( kondisi fisiologi dan kondisi panca indra), dan faktor psikologi (minat,efikasi diri, motivasi, kemandirian belajar, bakat dan kemampuan kognitif); kemudian yang kedua, faktor eksternal meliputi faktor lingkungan (alam,sosial budaya) dan faktor instrumental. efikasi diri adalah keyakinan diri yang diperoleh dari representasi mental dan kognitif individu atas realitas, yang terbentuk oleh pengalaman-pengalaman masa lalu dan masa kini, dan disimpan dalam memori. Dalam jangka panjang keyakinan ini mempengaruhi cara-cara sosialisasi yang akan dilakukan serta cara pandang seseorang terhadap kualitas dirinya sendiri, yang baik ataupun yang buruk, sehubungan dengan hal ini, efikasi diri adalahkeyakinan bahwa seseorang mampu menjalankan perilaku tertentu untuk mencapai tujuan tertentu.

Seseorang yang memiliki efikasi diri tinggi meyakini bahwa dirinya mampu untuk melakukan aktivitas yang akan dilakukannya. Sebaliknya, seseorang yang memiliki efikasi diri rendah tidak yakin akan kemampuannya dalam melaksanakan suatu aktivitas dan ini akan sangat berpengaruh terhadap prestasi belajar. Hal ini senada dengan penelitian Warsito (2009) Ada hubungan positif dan signifikan kausal antara efikasi diri dan prestasi akademik mahasiswa, dan juga penelitian Tenaw (2013) ada hubungan yang signifikan antara efikasi diri dan prestasi. Oleh karena itu untuk meningkatkan pemahaman siswa maka salah satunya dapat dilakukan dengan meningkatkan efikasi diri siswa.

\section{Simpulan}

Berdasarkan hasil penelitian yang telah dilakukan dapat ditarik kesimpulan bahwa: kemandirian belajar dan efikasi diri berpengaruh positif dan signifikan secara parsial dan simultan terhadap pemahaman akuntansi siswa SMA Negeri 1 Moyo Utara. Sehingga direkomendasikan bagi guru agar dapat memotivasi siswa untuk meningkatkan kemadirian belajar dan mempertahankan efikasi dirinya serta guru dan siswa dapat bekerja sama menciptakan proses belajar yang berkualitas agar siswa dapat meningkatkan pemahamannya terhadap materi yang dipelajari.

\section{Referensi}

Adicondro, N. \& Purnamasari, A. (2011). Efikasi Diri, Dukungan Sosial Keluarga dan Sefl Regulated Learning pada Mahasiswa Kelas VIII. Jurnal Humanitas. Vol. VIII. No. 01, $17-27$

Chairani, M. (2017). Pengaruh Efikasi Diri Dan Motivasi Belajar Terhadap Kemandirian Belajar Serta Implikasinya Terhadap Prestasi Belajar Mahasiswa. Jurnal Sains Ekonomi dan Edukasi Vol. V, No. I, 31-40

Susilawati, D. Upaya Meningkatkan Kemandirian Belajar Dan Kemampuan Matematika Siswa Kelas X SMA N 1 Gamping Dengan Menggunakan Lembar Kerja Siswa. (Yogyakarta: $U N Y, 2009)$

Saragih, D.K. (2014). Pengaruh Kemandirian, Gaya Belajar Dan Lingkungan Belajar Terhadap Hasil Belajar Akuntansi Siswa Kelas X Program Keahlian Akuntansi Smk PGRI 3 Sidoarjo. Vol. 2. No. 1

Djamarah, S. B. (2011). Psikologi Belajar. Banjarmasin: Rineka Cipta..

Kreitner, R. dan Kinicki, A. (2007). Organizational Behavior. $\quad 7^{\text {th }}$ edition. $\quad$ New $\quad$ York: McGraw-Hill. 
Lestari, Y., Y, \& Ranni, R. Z. (2015). Peningkatan Kemandirian BelajarDengan Layanan Bimbingan Kelompok. ALIBKIN (Jurnal Bimbingan Konseling) Vol 4. No 1.

Monika, A. (2017). Peran Efikasi Diri dan Motivasi Belajar dalam Meningkatkan Hasil Belajar Siswa Sekolah Menengah Kejuruan. Jurnal Pendidikan Manajemen Perkantoran, 1(1), 110-117.

Patmahsari, V. (2012).Pengaruh Pendekatan Belajar Tuntas (Mastery Learning) Terhadap Hasil Belajar Akuntansi Di SMA Negeri 13 Garut : Studi Quasi Eksperimen Pada Mata Pelajaran Akuntansi Kelas XI IPS, (Bandung : Skripsi Universitas Pendidikan Indonesia)

Priyatno, D. (2008). Mandiri Belajar SPSS (Statistical Product and Service Solution) untuk analisis data dan uji statistik. Yogyakarta : MediaKom.

Saputri, D. (2013). Pengaruh Kesiapan, Kemandirian dan Lingkungan Belajar Terhadap Prestasi Akademik Mahasiswa Pendidikan Ekonomi Universitas Negeri Padang. Jurnal Universitas Negeri Padang, 1-14.

Suhendri, H, Pengaruh Kecerdasan Matematika-Logi, Rasa Percaya Diri, dan Kemandirian Belajar terhadap Hasil Belajar Matematika. Jurnal Formatif, 29-39.

Tenaw, Y. A (2013). "Relationship BetweenSelf efficacy, Academic Achievement and Gender in Analytical Chemistry at Debre Markos College Of Teacher Education".AJCE . vol 3. No.1, 3-28. 